Received 04.03.2017

Reviewed 23.06.2017

Accepted 04.07.2017

A - study design

B - data collection

C - statistical analysis

D - data interpretation

$\mathbf{E}$ - manuscript preparation

F - literature search

\section{Evaluation of synthetic rainfall application with respect to the flow volume at upstream Brantas watershed, East Java Province of Indonesia}

\author{
Lily Montarcih LIMANTARA ${ }^{\text {ADF } \bowtie}$, Donny HARISUSENO ${ }^{\text {CE }}$, \\ Rana Karinta HAPSARI ${ }^{\text {BDE }}$
}

University of Brawijaya, Faculty of Engineering, Department of Water Resources, J1. Mt Haryono No 167, 65141 Malang, East Java Province, Indonesia; e-mail: lilymont2001@gmail.com, donnyhari@yahoo.com, ranakarinta@yahoo.com

For citation: Limantara L.M., Harisuseno D., Hapsari R.K. 2017. Evaluation of synthetic rainfall application with respect to the flow volume at upstream Brantas watershed, East Java Province of Indonesia. Journal of Water and Land Development. No. 35 p. 129-136. DOI: 10.1515/jwld-2017-0076.

\begin{abstract}
Indonesian Technical Implementation Unit (UPT) of Synthetic Rainfall has modified climate by generating synthetic rainfall from $9^{\text {th }}$ May until $4^{\text {th }}$ June 2013. This unit has cooperated with the Department of Technological Study and Application (BPPT) of Indonesia and Perum Jasa Tirta I and TNI AU Lanud Abdulrachman Saleh. This study intended to increase reservoirs water level in upstream Brantas watershed, one of them is Sutami reservoir. Successive grade evaluation of synthetic rainfall used the method of Double Ratio and Flow Discharge. The target area is upstream Brantas watershed that is represented by 12 rainfall stations and the control area is in the distance of $\pm 30 \mathrm{~km}$ from the boundary of upstream Brantas watershed and is represented by 5 rainfall stations. Results show rainfall increasing by $152.05 \%$ according to the Double Ratio method and the increase of flow discharge from Sutami reservoir by $74.19 \%$ according to the Flow Discharge method.
\end{abstract}

Key words: control area, double ratio, flow discharge, synthetic rainfall, target area

\section{INTRODUCTION}

Drought is one of the most important natural hazards which is presented a serious problem mainly for human societies and ecosystems [KHEZAZNA et.al. 2017]. The longer dry season causes drought disaster [ARAGHINEJAD 2011; KALYANAPU et al. 2009] in Indonesia. Significant decrease of precipitation causes the disruption of natural ecosystems and trouble with water management [BĄK, KUBIAK-WÓJCICKA 2017]. Drought gives the impact on the decreasing of water level elevation in some reservoirs [VANGELIS et al. 2011] which are managed by Perum Jasa Tirta I, East Java Province of Indonesia. One of the reservoirs that are decreasing of water level is Sutami reservoir on 2013. However, although there has not started on dry season but the inflow in Sutami reservoir is on the number of 75.5 $\mathrm{m}^{3} \cdot \mathrm{s}^{-1}$, while the ideal number which is determined by East Java Province Government is $96.5 \mathrm{~m}^{3} \cdot \mathrm{s}^{-1}$. The water level elevation of Sutami reservoir has not sharply decreased, but Perum Jasa Tirta I is remained to target the increasing of water level elevation before the peak of dry season. Some efforts have been carried out by the government for anticipating the problem; one of them is to apply the technology of synthetic rainfall.

Technology of synthetic rainfall has been carried out several times in Indonesia. However it still becomes as a problem about the dropped rainfall. Evaluation of the synthetic rainfall is carried out for knowing the comparison between rainfall depth on the synthetic rainfall period and natural rainfall which is estimated dropping if there is no synthetic rainfall activity or to compare the direct flow volume during the synthetic rainfall activity. To evaluate the rainfall, the measuring 
result of rainfall is carried out during the synthetic rainfall takes place and it is as the total rainfall such as the amount of natural rainfall and the result of synthetic rainfall which both of them have been mixed. The synthetic rainfall activity is carried out by the Technical Implementer Unit (UPT) of Indonesia which has corporates with the Department of Technology Study and Application and the institution of Perum Jasa Tirta I and TNI AU Lanud Abdurachman Saleh-Indonesia on $9^{\text {th }}$ May until $4^{\text {th }}$ June 2013 . Result of the synthetic rainfall showed that there was depth increasing of water level in Sutami Reservoir of $1.19 \mathrm{~m}$ and it was increasing the inflow volume of $131,718,528 \mathrm{~m}^{3}$.

This study intended to know the increasing level of rainfall on upstream Brantas watershed after applying the synthetic rainfall activity. The methodology is using the Double Ratio method for evaluating the rainfall increasing and Flow Discharge method on Sutami reservoir for evaluating the flow increasing due to the synthetic rainfall from $9^{\text {th }}$ May until $4^{\text {th }}$ June 2013.

\section{MATERIALS AND METHODS}

Brantas watershed in East Java Province of Indonesia is as an area where has strategic value. River water in Brantas watershed is used for some demands such as irrigation, domestic water for Regional Manufactory of Drinking Water (PDAM), industry, hydro electrical power (PLTA), fishery, flushing, and recreation. Area of Brantas watershed is $12,000 \mathrm{~km}^{2}$ which includes less than $25 \%$ of East Java Province with the potency of water resources is \pm 12 billion $\mathrm{m}^{3}$ per-year.

The upstream Brantas watershed has variety of topography beginning from plain until mountains. This condition reflects that there is the variety of environent such as relief, micro climate, type and age of material. Material, relief, micro climate, age and vegetation are as the main factors of soil formers. Plain area is found on the area with the height $<800 \mathrm{~m}$. Area with flat and rather flat are many used as the agricultural plantation area for seasonal commodity and horticulture which is intensively managed throughout the year. The hills area is found in the height range from $800 \mathrm{~m}$ until $1,000 \mathrm{~m}$. Sumber Brantas Watershed is one out of sub catchments of the Upper Brantas River, situated in Batu District, East Java, Indonesia and covering an area about $174 \mathrm{~km}^{2}$ Recently, the hydrology of the watershed was considered to be degraded in terms of the quality and quantity of water yield. Fast floods were more often during the rainy seasons, while droughts were more severe during the dry seasons. Much spring water dried out in the dry seasons and two-third of them dried out permanently in the last decade. The condition was often related to the rapid change of land use in the watershed. The natural forest and agroforestry gardens were converted into rain fed agriculture. Analysis on land sat images from 1989 and 2002 showed that 3.702 ha of natural forest and 1.153 ha of agroforestry gardens has disappeared. Further analysis showed that the area of rain fed agriculture, settlements and shrubs were increasing during that period. This most likely related to the socio-economics conditions of local community as well as the variability of stakeholders perception in best watershed management planning and practices

The upstream Brantas watershed is as the target area of synthetic rainfall and it is as part of Brantas watershed with number area of $2,100 \mathrm{~km}^{2}$ and there are 3 reservoirs in it such as Sengguruh, Sutami, and Lahor. Figure 1 presents the flight target and control area of synthetic rainfall operation. Figure 2 illustrate the position of rainfall station in target and control area.

The supporting data which are needed in this study are as follow.

1. Daily rainfall data in target area from May until June 2013. Target area includes upstream Brantas watershed which is represented by 12 rainfall stations such as Dau, Pujon, Karangkates, Ciliwung, Sukun, Kedungrejo, Singosari, Jabung, Dampit, Wagir, Poncokusumo, and Sumberpucung.

2. Historical inflow (discharge) in Sutami reservoir from 1991 to 2010. Tahe catchment area of Sutami is $2,050 \mathrm{~km}^{2}$ and the reservoir capacity is $343,000,000 \mathrm{~m}^{3}$.

3. Daily rainfall in control area from May until June, 1991-2011. Control area is located in the distance of $\pm 30 \mathrm{~km}$ from the boundary of upstream Brantas watershed and it is represented by 5 rainfall stations such as Wlingi, Doko, Sumberagung, Birowo, and Semen.

4. Literatures which are related to this study.

Data analysis in this study is carried out into some steps. The first step is hydrological analysis [ASDAK 2010] and the next step is success grade evaluation of the synthetic rainfall. However, the steps of hydrological analysis are as follow.

1. To collect daily rainfall during the process of synthetic rainfall such as from May to June 2013.

2. To analyse maximum regional mean rainfall by using Arithmetic method [HARTO 1993; SOEMARTO 1987; SOSRODARSONO 1983].

3 . To evaluate the success grade of the synthetic rainfall by using the methods of Double Ratio and Flow Discharge.

The steps of evaluation grade on the synthetic rainfall by using Double Ratio method are as follow.

1. To collect daily rainfall during the activity process of synthetic rainfall such as from May to June 2013 for target and control area.

2. To collect historical daily rainfall from May to June, 1991-2010 for target and area control.

3. To estimate rainfall in target and control area.

4. To analyse historical regional mean rainfall for target and control area by using Arithmetic method [HARTO 1993; SOEMARTO 1987; SOSRODARSONO 1983].

5. To analyse the difference between actual and estimation rainfall each in target and control area. 


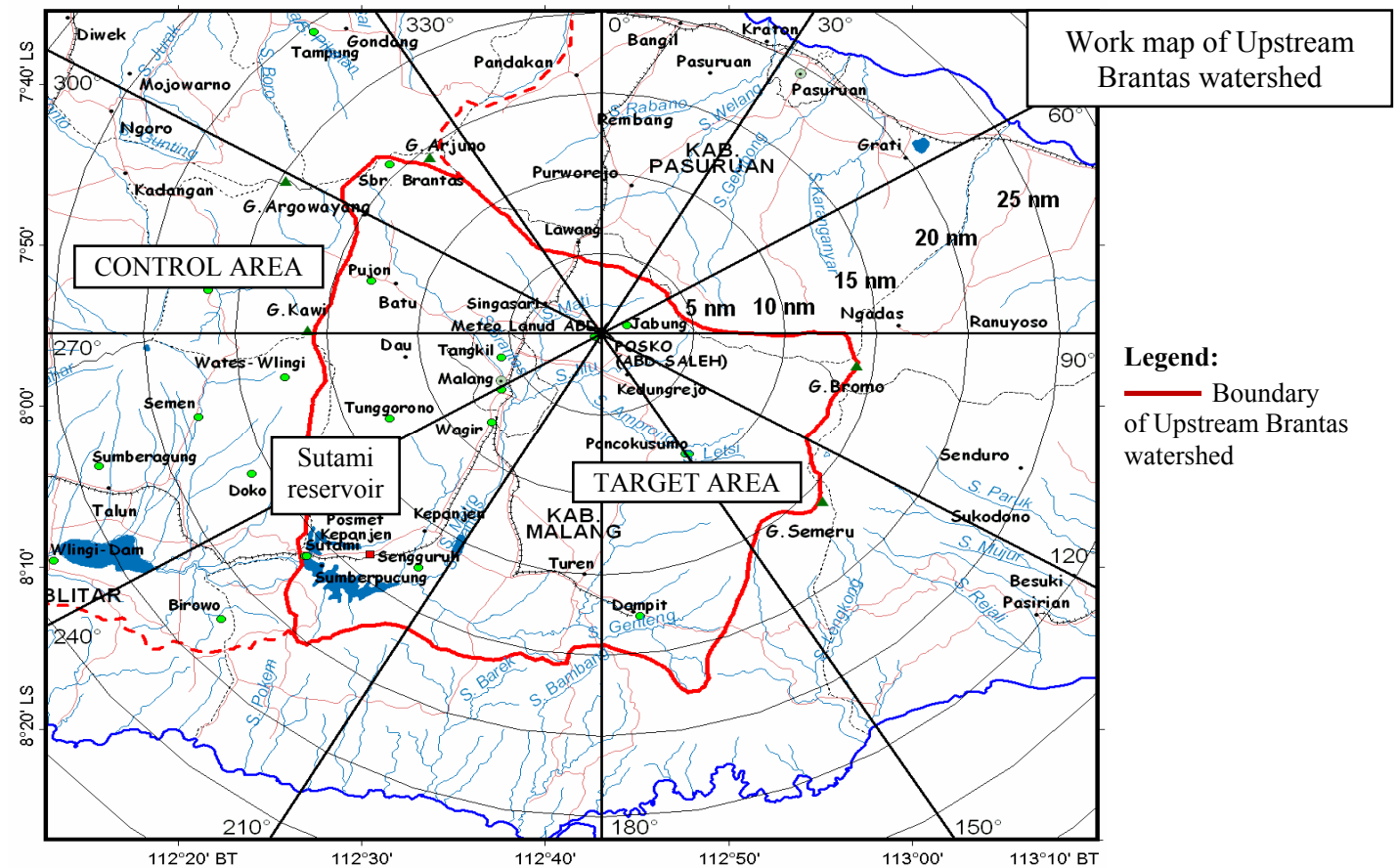

Fig. 1. Flight target and control area of synthetic rainfall operation; source: Department of Technological Study and Application, Indonesia [2013]

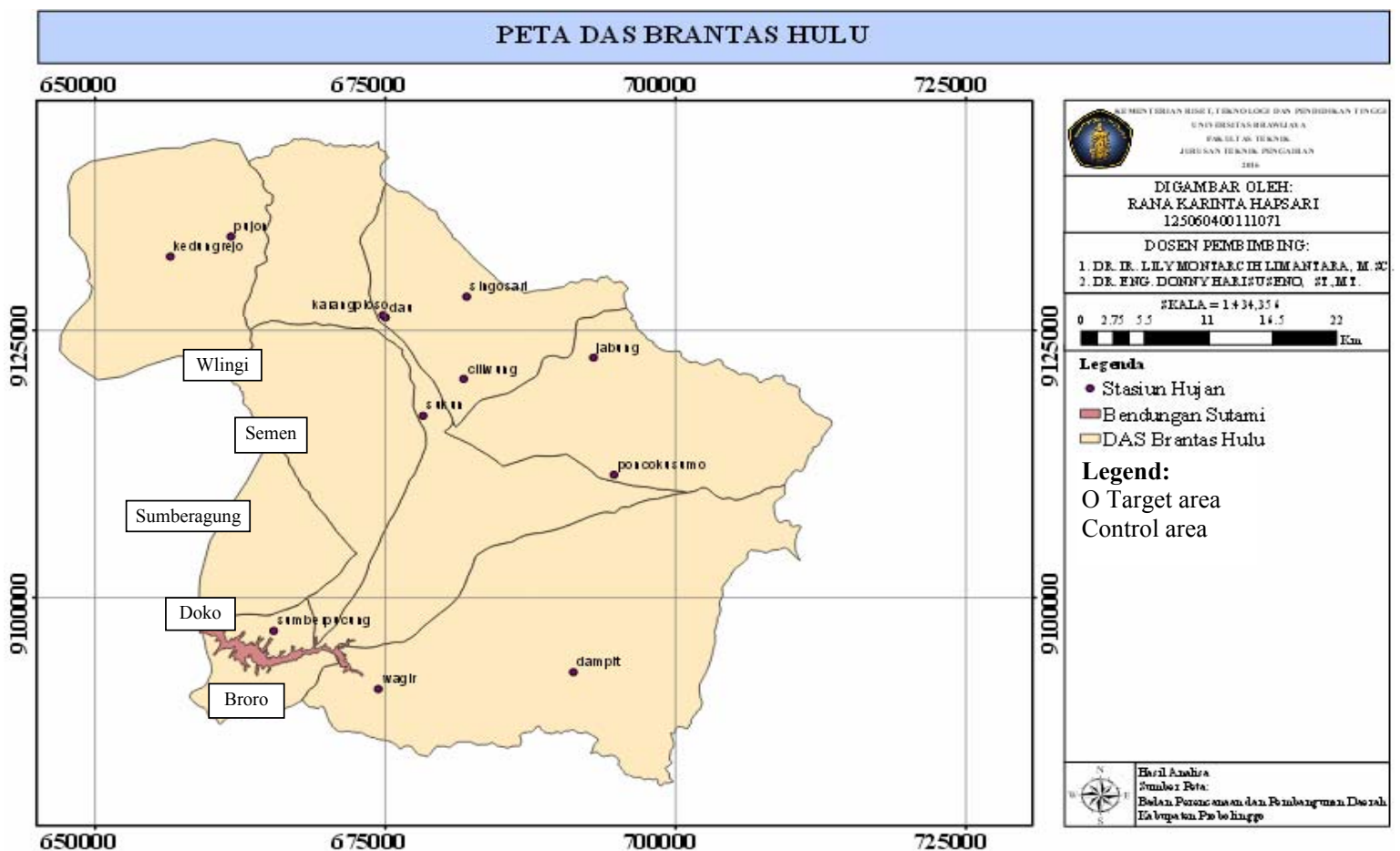

Fig. 2. The position of rainfall station in target and control area; source: Department of Technological Study and Application, Indonesia [BPPT 2013]

The steps of evaluation grade on the synthetic rainfall by using Flow Discharge method are as follow:

1. To collect inflow data of Sutami reservoir during the activity process of synthetic rainfall such as from May to June 2013.

2. To collect historical inflow discharge of Sutami reservoir during the activity process of synthetic rainfall such as from May to June, 1991-2011.
3. To analyse the base flow for historical inflow which is obtained from historical inflow of Sutami reservoir from 1991 to 2011 and from actual inflow

4. To analyse the historical and actual direct flow volume.

5. To analyse the difference and deviation between historical and actual volume of direct flow when the activity of synthetic rainfall. 
Synthetic rainfall is as an innovation which is created in order to accelerate and to increase the rainfall. There is needed cloud with high water content and slow wind velocity for making the synthetic rainfall. The synthetic rainfall is made by sowing the hygroscopes materials [BELYAEVA et al. 2017]. The particles can increase number of water particles in the cloud and accelerating the happening of rainfall. Condensation process is happening on the particles that have low $\mathrm{pH}$ (acid). The selection of good salt is also as the important function in increasing the condensation process in the cloud.

Salt which is generally used is $\mathrm{NaCl}$ (sodium chloride) and $\mathrm{CaCl}_{2}$ (calcium chloride). The salt has good enough hygroscopes value and easy to be obtained. Type of Cumulus cloud is a good cloud as the media for making the synthetic rainfall. The characteristic of Cumulus cloud is the performance with the col flower form with the condition is not higher than 5,000 feet and the peak is higher than 11,000 feet. Table 1 presents the process of synthetic rainfall making.

Table 1. Making process of synthetic rainfall

\begin{tabular}{|l|l|}
\hline \multicolumn{1}{|c|}{ Activity } & \multicolumn{1}{c|}{ Objective } \\
\hline To distribute or to sow $\mathrm{CaCl}_{2}$ & to produce and to increase cloud \\
\hline To distribute or to sow $\mathrm{NaCl}$ & to tamp cloud \\
\hline $\mathrm{CO}_{2}$ & $\begin{array}{l}\text { to decrease the temperature } \\
\text { of cloud and salt so it can be reached } \\
\text { the dewdrop }\end{array}$ \\
\hline To distribute or to sow urea & $\begin{array}{l}\text { to decrease the temperature of cloud } \\
\text { and to accelerate the condensation } \\
\text { process in the cloud }\end{array}$ \\
\hline
\end{tabular}

Source: Sekretariat Kabinet Republik Indonesia [2013].

In the activity of synthetic rainfall which was carried out by Technical Implementer Unit (UPT) of synthetic rainfall, sowing materials were released in the cloud. Based on the activity experience in field, for number target area of $3.500 \mathrm{~km}^{2}$ is generally looked on 5-6 clouds with medium size due to the potency criteria that is determined by Mission Scientist on board with single organization or 2-3 big clouds with embedded or complex organization. There are 800$1000 \mathrm{~kg}$ of sowing materials taken on every flight, are sown into the cloud. The sowing material will be exhausted in 15-20 min or in the average is $50 \mathrm{~kg} \cdot \mathrm{min}^{-1}$.

Analysis of Double Ratio is as the comparison between the ratio between rainfall in target and control area in the range time of cloud sowing and no sowing in the same time. The method intends to know the increasing grade of rainfall by missing or decreasing the variety of available natural rainfall when the implementation of synthetic rainfall. Effect of sowing is assumed positive if the value of $D R>1$.

The estimation of rainfall in control area uses the regression equation. Control area is as an area which has the distance about $30 \mathrm{~km}$ from the boundary of target area. The relation between rainfall in target and control area is evaluated by statistic and has to have a close correlation $(r>0.7)$. The formula of this method is as follow [BELYAEVA et al. 2011]:

$$
\begin{gathered}
D R=(T / C)_{a} /(T / C)_{u s} \\
D R(\%)=(D R-1) \cdot 100 \%
\end{gathered}
$$

where: $D R=$ value of Double Ratio; $D R(\%)=$ rainfall increasing, \%; $(T / C)_{a}=$ ratio of rainfall target and control area on the range time of cloud sowing; $(T / C)_{u s}=$ ratio of rainfall target and control area on the range time of not cloud sowing.

Method of flow discharge uses the ratio between flow discharge when there is the activity and no activity of synthetic rainfall. Estimation of flow discharge when there is no synthetic rainfall activity is using the historical data and hydrological model. The increasing grade of flow discharge is as follow [BELYAEVA et al. 2017]:

$$
R=Q_{H B}-Q_{A}
$$

where: $R=$ grade of flow increasing, $\mathrm{m}^{3} ; Q_{H B}=$ discharge when there is synthetic rainfall activity, $\mathrm{m}^{3}$; $Q_{A}=$ discharge when there is no synthetic rainfall activity, $\mathrm{m}^{3}$.

\section{RESULTS AND DISCUSSION}

This study used 12 rainfall stations in target area and 5 rainfall stations in control area. The close correlation between both of them enables the predicted rainfall which is happened in control area is as the happened rainfall in target area if there is no synthetic rainfall activity. Table 2 and 3 present the location of rainfall stations which represent the target and control area.

Table 2. Location of rainfall area in target area (upstream Brantas watershed)

\begin{tabular}{|l|c|c|}
\hline \multirow{2}{*}{ Rainfall station } & \multicolumn{2}{|c|}{ Coordinate } \\
\cline { 2 - 3 } & South longest & East longest \\
\hline Dau & $07^{\circ} 54^{\prime} 8,47^{\prime \prime}$ & $112^{\circ} 35^{\prime} 1,64^{\prime \prime}$ \\
\hline Pujon & $07^{\circ} 50^{\prime} 3,56^{\prime \prime}$ & $112^{\circ} 28^{\prime} 0,34^{\prime \prime}$ \\
\hline Karangploso & $07^{\circ} 57^{\prime} 1,42^{\prime \prime}$ & $112^{\circ} 38^{\prime} 5,68^{\prime \prime}$ \\
\hline Ciliwung & $07^{\circ} 57^{\prime} 1,42^{\prime \prime}$ & $112^{\circ} 38^{\prime} 5,68^{\prime \prime}$ \\
\hline Sukun & $07^{\circ} 59^{\prime} 6,73^{\prime \prime}$ & $112^{\circ} 37^{\prime} 2,84^{\prime \prime}$ \\
\hline Singosari & $07^{\circ} 53^{\prime} 4,12^{\prime \prime}$ & $112^{\circ} 39^{\prime} 4,13^{\prime \prime}$ \\
\hline Kedungrejo & $07^{\circ} 51^{\prime} 5,22^{\prime \prime}$ & $112^{\circ} 25^{\prime} 9,61^{\prime \prime}$ \\
\hline Wagir & $08^{\circ} 31^{\prime} 1,42^{\prime \prime}$ & $112^{\circ} 35^{\prime} 5,68^{\prime \prime}$ \\
\hline Sumberpucung & $08^{\circ} 10^{\prime} 3,42^{\prime \prime}$ & $112^{\circ} 30^{\prime} 5,12^{\prime \prime}$ \\
\hline Jabung & $07^{\circ} 56^{\prime} 7,55^{\prime}$ & $112^{\circ} 45^{\prime} 1,01^{\prime \prime}$ \\
\hline Poncokusumo & $08^{\circ} 02^{\prime} 4,66^{\prime \prime}$ & $112^{\circ} 46^{\prime} 0,93^{\prime \prime}$ \\
\hline Dampit & $06^{\circ} 57^{\prime} 6,06^{\prime \prime}$ & $112^{\circ} 34^{\prime} 8,69^{\prime \prime}$ \\
\hline
\end{tabular}

Source: Great Institution of Technology, Indonesia [BPPT 2016].

Table 3. Location of rainfall station in control area

\begin{tabular}{|l|c|c|}
\hline \multirow{2}{*}{ Rainfall station } & \multicolumn{2}{|c|}{ Coordinate } \\
\cline { 2 - 3 } & South longest & East longest \\
\hline Birowo & $08^{\circ} 34^{\prime} 7,36^{\prime \prime}$ & $112^{\circ} 55^{\prime} 1,64^{\prime \prime}$ \\
\hline Sumberagung & $08^{\circ} 71^{\prime} 4,23^{\prime \prime}$ & $112^{\circ} 60^{\prime} 0,34^{\prime \prime}$ \\
\hline Wlingi & $08^{\circ} 88^{\prime} 5,42^{\prime \prime}$ & $112^{\circ} 66^{\prime} 5,68^{\prime \prime}$ \\
\hline Semen & $08^{\circ} 65^{\prime} 5,22^{\prime \prime}$ & $112^{\circ} 53^{\prime} 5,68^{\prime \prime}$ \\
\hline Doko & $08^{\circ} 96^{\prime} 6,73^{\prime \prime}$ & $112^{\circ} 56^{\prime} 2,84^{\prime \prime}$ \\
\hline
\end{tabular}

Source: Great Institution of Technology, Indonesia [BPPT 2016]. 
Activity of synthetic rainfall has carried out from $9^{\text {th }}$ May to $4^{\text {th }}$ June 2013 in target area such as upstream Brantas watershed. Flight is regarded with the level of the maturity available cloud. Execution flight of cloud sowing is guided by flight scientist who has the ability in seeing, deciding what has to be carried out during the flight and executing. During the implementation of synthetic rainfall from $9^{\text {th }}$ May to $4^{\text {th }}$ June 2013 , there has been carried out as 29 times sowing flight. Total of flight hour is 32 hours 36 minutes and it spends the sowing materials of $34,000 \mathrm{~kg}$.

Data which is used in this study comes from 12 rainfall stations in target area and 5 rainfall stations in control area. There is closely relation between both of them and it gives the possibility that the predicted rainfall in control area is as the happening rainfall in target area if there is no synthetic rainfall. Table 4 and 5 present the correlation between historical rainfall in target and control area.

Table 4. Correlation analysis of historical rainfall between target and control area (1991-2011)

\begin{tabular}{|c|r|r|r|r|}
\hline \multirow{2}{*}{ Year } & \multicolumn{2}{|c|}{ May, mm } & \multicolumn{2}{c|}{ June, mm } \\
\cline { 2 - 5 } & target & control & target & control \\
\hline 1991 & 3.42 & 0.00 & 0.00 & 0.00 \\
\hline 1992 & 79.75 & 108.80 & 9.17 & 16.20 \\
\hline 1993 & 16.33 & 28.40 & 0.00 & 0.00 \\
\hline 1994 & 24.83 & 36.00 & 0.00 & 0.00 \\
\hline 1995 & 9.67 & 2.60 & 0.00 & 0.00 \\
\hline 1996 & 4.25 & 0.40 & 3.33 & 0.00 \\
\hline 1997 & 10.58 & 12.80 & 0.00 & 0.00 \\
\hline 1998 & 22.92 & 31.60 & 8.17 & 8.00 \\
\hline 1999 & 37.92 & 43.80 & 0.00 & 0.00 \\
\hline 2000 & 106.58 & 114.80 & 5.08 & 6.40 \\
\hline 2001 & 22.42 & 16.00 & 52.67 & 36.00 \\
\hline 2002 & 70.42 & 86.20 & 0.00 & 8.60 \\
\hline 2003 & 54.67 & 50.00 & 0.00 & 1.00 \\
\hline 2004 & 88.71 & 78.80 & 0.00 & 0.60 \\
\hline 2005 & 7.17 & 8.80 & 6.17 & 3.20 \\
\hline 2006 & 128.50 & 140.60 & 11.67 & 3.00 \\
\hline 2007 & 44.92 & 57.60 & 25.17 & 79.40 \\
\hline 2008 & 14.00 & 37.00 & 4.25 & 2.20 \\
\hline 2009 & 179.92 & 217.20 & 6.00 & 20.80 \\
\hline 2010 & 243.25 & 266.20 & 13.83 & 7.60 \\
\hline 2011 & 113.58 & 106.00 & 5.58 & 0.00 \\
\hline Mean & $\mathbf{6 1 . 1 3}$ & $\mathbf{6 8 . 7 4}$ & $\mathbf{7 . 1 9}$ & $\mathbf{9 . 1 9}$ \\
\hline
\end{tabular}

Source: own study.

Table 5. Result of statistical analysis

\begin{tabular}{|l|c|c|}
\hline \multirow{2}{*}{ Regression statistic } & \multicolumn{2}{|c|}{ Summary output } \\
\cline { 2 - 3 } & May & June \\
\hline Multiple $R$ & 0.935226 & 0.981198 \\
\hline$R^{2}$ & 0.887447 & 0.962749 \\
\hline Adjusted $R^{2}$ & 0.822015 & 0.910117 \\
\hline Standard error & 27.63048 & 24.93776 \\
\hline Observations & 21 & 21 \\
\hline
\end{tabular}

Source: own study.

Analysis of correlation uses the linear regression such as by comparing the historical rainfall data during 21 years before the synthetic rainfall activity in target and control area. Result shows that there is close rela- tion between both of them with determination coefficient: $R^{2}=0.91$ and correlation coefficient $R=0.96$. Rainfall data which is used for finding the mean rainfall in target area is data of $9^{\text {th }}$ May $-4^{\text {th }}$ June 2013 when the process of synthetic rainfall. The mean of rainfall in the target area when the activity of synthetic rainfall is carried out, is presented in the Table 6 .

Rainfall data which is used for finding the mean rainfall in control area is data of $9^{\text {th }}$ May- $4^{\text {th }}$ June 2013 when the process of synthetic rainfall. The mean of rainfall in control area when the activity of synthetic rainfall is carried out, is presented as in Table 7.

Table 6. Mean rainfall in target area due to the arithmetic method on $9^{\text {th }}$ May $-4^{\text {th }}$ June 2013

\begin{tabular}{|c|l|c|}
\hline Year & Rainfall station & Rainfall, $\mathrm{mm}$ \\
\hline 2013 & Dau & 228 \\
\hline 2013 & Pujon & 237 \\
\hline 2013 & Karangploso & 94 \\
\hline 2013 & Ciliwung & 206 \\
\hline 2013 & Sukun & 225 \\
\hline 2013 & Singosari & 114 \\
\hline 2013 & Kedungrejo & 128 \\
\hline 2013 & Wagir & 216 \\
\hline 2013 & Sumberpucung & 281 \\
\hline 2013 & Jabung & 112 \\
\hline 2013 & Poncokusumo & 158 \\
\hline 2013 & Dampit & 202 \\
\hline Total & & $\mathbf{2 2 0 1}$ \\
\hline Mean & & $\mathbf{1 8 3 . 4 2}$ \\
\hline
\end{tabular}

Source: own study.

Table 7. Mean rainfall in control area due to the arithmetic method on $9^{\text {th }}$ May $-4^{\text {th }}$ June 2013

\begin{tabular}{|c|c|l|c|}
\hline No. & Year & Rainfall station & Rainfall, $\mathrm{mm}$ \\
\hline 1 & 2013 & Birowo & 217 \\
\hline 2 & 2013 & Sumberagung & 31 \\
\hline 3 & 2013 & Semen & 110 \\
\hline 4 & 2013 & Wlingi & 42 \\
\hline 5 & 2013 & Doko & 15 \\
\hline \multicolumn{2}{|l}{} & $\mathbf{4 1 5}$ \\
\hline Total & $\mathbf{8 3}$ \\
\hline
\end{tabular}

Source: own study.

The result is at least partially by natural variation of rainfall in the target and control area. However, the result is used as the rainfall of control area when the cloud sowing by using Double Ratio method. However, analysis of historical rainfall intends to obtain mean of historical rainfall on $9^{\text {th }}$ May to $4^{\text {th }}$ June in target and control area. Mean historical rainfall which is used in this study is from 1991 to 2011 . The result is used for analysing the rainfall increasing by using Double Ratio method.

Mean of area target on $9^{\text {th }}$ May to $4^{\text {th }}$ June is $68.32 \mathrm{~mm}$ and in control area is $77.93 \mathrm{~mm}$. This result is used for analysing the rainfall increasing by using Double Ratio method when there is no cloud sowing.

Model of rainfall estimation on May and June 2013 is built by using linear regression due to the historical data in target and control area on May-June 1991-2011. Result of analysis shows that total of 
rainfall when the process of synthetic rainfall $\left(9^{\text {th }}\right.$ May to $4^{\text {th }}$ June 2013) is $112.95 \mathrm{~mm}$. Table 8 presents the recapitulation of rainfall in target and control area.

Table 8. Recapitulation of rainfall in target and control area

\begin{tabular}{|l|c|c|}
\hline \multicolumn{1}{|c|}{ Note } & Target, $\mathrm{mm}$ & Control, $\mathrm{mm}$ \\
\hline Actual & 183.42 & 83.00 \\
\hline Historic & 68.32 & 77.93 \\
\hline
\end{tabular}

Source: own study.

Analysis of synthetic rainfall increasing based on the Double Ratio is as follow:

$$
\begin{gathered}
D R=(T / C)_{a} /(T / C)_{u s}= \\
=(183.42 / 83) /(68.32 / 77.93)=2.5205 \\
D R(\%)=(D R-1) \times 100 \%= \\
=(2.5205-1) \times 100 \%=152.05 \%
\end{gathered}
$$

Result of analysis shows that the rainfall increasing due to the synthetic rainfall is $152.05 \%$. The evaluation is due to the Flow Discharge method by using historical inflow discharge of Sutami reservoir during 21 years such as from 1991 to 2011, because during the 21 years there is no activity of synthetic rainfall so it can be concluded that the happening rainfall is as the natural one. Data of historical inflow discharge which is used is inflow discharge from May to June regarding to the activity of synthetic rainfall. Table 9 presents the analysis of historical/actual direct flow volume for the period

\begin{tabular}{|c|c|c|c|c|}
\hline Date & $\begin{array}{l}\text { Inflow } \\
\mathrm{m}^{3} \cdot \mathrm{s}^{-1}\end{array}$ & $\begin{array}{c}\text { Base flow } \\
\mathrm{m}^{3} \cdot \mathrm{s}^{-1}\end{array}$ & $\begin{array}{c}\text { Direct flow } \\
\text { discharge } \\
\mathrm{m}^{3} \cdot \mathrm{s}^{-1}\end{array}$ & $\begin{array}{l}\text { Direct flow } \\
\text { volume } \\
\text { million } \mathrm{m}^{3}\end{array}$ \\
\hline 09.05 & 80.37 & 23.40 & 56.97 & 113.22 \\
\hline 10.05 & 76.43 & 23.40 & 53.03 & 105.37 \\
\hline 11.05 & 81.56 & 23.40 & 58.16 & 115.57 \\
\hline 12.05 & 76.83 & 23.40 & 53.43 & 106.17 \\
\hline 13.05 & 72.12 & 23.40 & 48.72 & 96.81 \\
\hline 14.05 & 71.24 & 23.40 & 47.84 & 95.06 \\
\hline 15.05 & 71.99 & 23.40 & 48.59 & 96.56 \\
\hline 16.05 & 74.30 & 23.40 & 50.90 & 101.15 \\
\hline 17.05 & 67.41 & 23.40 & 44.01 & 87.46 \\
\hline 18.05 & 67.31 & 23.40 & 43.91 & 87.26 \\
\hline 19.05 & 69.64 & 23.40 & 46.24 & 91.90 \\
\hline 10.05 & 73.02 & 23.40 & 49.62 & 98.61 \\
\hline 21.05 & 71.50 & 23.40 & 48.10 & 95.57 \\
\hline 22.05 & 67.99 & 23.40 & 44.59 & 88.60 \\
\hline 23.05 & 63.28 & 23.40 & 39.88 & 79.25 \\
\hline 24.05 & 66.52 & 23.40 & 43.12 & 85.69 \\
\hline 25.05 & 63.66 & 23.40 & 40.26 & 80.01 \\
\hline 26.05 & 68.19 & 23.40 & 44.79 & 89.01 \\
\hline 27.05 & 63.84 & 23.40 & 40.44 & 80.35 \\
\hline 28.05 & 64.15 & 23.40 & 40.75 & 80.99 \\
\hline 29.05 & 67.30 & 23.40 & 43.90 & 87.24 \\
\hline 30.05 & 66.99 & 23.40 & 43.59 & 86.63 \\
\hline 31.05 & 68.59 & 23.40 & 45.19 & 89.81 \\
\hline 01.06 & 63.42 & 27.51 & 35.91 & 12.41 \\
\hline 02.06 & 61.28 & 27.51 & 33.77 & 11.67 \\
\hline 03.06 & 61.13 & 27.51 & 33.62 & 11.62 \\
\hline 04.06 & 64.22 & 27.51 & 36.71 & 12.69 \\
\hline
\end{tabular}
of $9^{\text {th }}$ May- $4^{\text {th }}$ June (1991-2011).

Table 9. Analysis of historical/actual direct flow volume for the period of $9^{\text {th }}$ May $-4^{\text {th }}$ June (1991-2011)

Source: own study.
The result above will be compared with direct flow volume when the activity of synthetic rainfall such as on $9^{\text {th }}$ May- $4^{\text {th }}$ June 2013. Analysis of actual direct flow volume can be seen as in Table 10.

Table 10. Analysis of actual direct flow volume on $9^{\text {th }}$ May to $4^{\text {th }}$ June 2013

\begin{tabular}{|c|c|c|c|c|}
\hline Date & $\begin{array}{c}\text { Inflow } \\
\mathrm{m}^{3} \cdot \mathrm{s}^{-1}\end{array}$ & $\begin{array}{c}\text { Base flow } \\
\mathrm{m}^{3} \cdot \mathrm{s}^{-1}\end{array}$ & $\begin{array}{c}\text { Direct flow } \\
\text { discharge } \\
\mathrm{m}^{3} \cdot \mathrm{s}^{-1}\end{array}$ & $\begin{array}{c}\text { Direct flow } \\
\text { volume } \\
\text { million } \mathrm{m}^{3}\end{array}$ \\
\hline 09.05 .2013 & 75.13 & 23.40 & 51.73 & 102.8 \\
\hline 10.05 .2013 & 66.00 & 23.40 & 42.60 & 84.65 \\
\hline 11.05 .2013 & 70.90 & 23.40 & 47.50 & 94.39 \\
\hline 12.05 .2013 & 75.37 & 23.40 & 51.97 & 103.27 \\
\hline 13.05 .2013 & 77.72 & 23.40 & 54.32 & 107.94 \\
\hline 14.05 .2013 & 78.09 & 23.40 & 54.69 & 108.68 \\
\hline 15.05 .2013 & 77.63 & 23.40 & 54.23 & 107.77 \\
\hline 16.05 .2013 & 83.65 & 23.40 & 60.25 & 119.73 \\
\hline 17.05 .2013 & 90.83 & 23.40 & 67.43 & 134.00 \\
\hline 18.05 .2013 & 123.38 & 23.40 & 99.98 & 198.68 \\
\hline 19.05 .2013 & 126.73 & 23.40 & 103.33 & 205.34 \\
\hline 20.05 .2013 & 80.10 & 23.40 & 56.70 & 112.67 \\
\hline 21.05 .2013 & 83.02 & 23.40 & 59.62 & 118.48 \\
\hline 22.05 .2013 & 93.87 & 23.40 & 70.47 & 140.04 \\
\hline 23.05 .2013 & 112.31 & 23.40 & 88.91 & 176.68 \\
\hline 24.05 .2013 & 117.64 & 23.40 & 94.24 & 187.27 \\
\hline 25.05 .2013 & 119.34 & 23.40 & 95.94 & 190.65 \\
\hline 26.05 .2013 & 187.06 & 23.40 & 163.66 & 325.23 \\
\hline 27.05 .2013 & 143.79 & 23.40 & 120.39 & 239.24 \\
\hline 28.05 .2013 & 113.68 & 23.40 & 90.28 & 179.4 \\
\hline 29.05 .2013 & 120.14 & 23.40 & 96.74 & 192.24 \\
\hline 30.05 .2013 & 129.99 & 23.40 & 106.59 & 211.82 \\
\hline 31.05 .2013 & 139.84 & 23.40 & 116.44 & 231.39 \\
\hline 01.06 .2013 & 101.04 & 27.51 & 73.53 & 25.41 \\
\hline 02.06 .2013 & 104.15 & 27.51 & 76.64 & 26.49 \\
\hline 03.06 .2013 & 92.58 & 27.51 & 65.07 & 22.49 \\
\hline 04.06 .2013 & 79.47 & 27.51 & 51.96 & 17.96 \\
\hline
\end{tabular}

Source: own study.

Historical inflow discharge is used for finding the mean volume of direct flow. Then, the value will be compared with the mean volume of direct flow when there is the activity of synthetic rainfall on 2013. The difference between both of them is as the success grade of the synthetic rainfall. Table 11 presents the minimum inflow historical discharge in Sutami reservoir in 1991-2011.

Based on the result as above, it shows that the minimum discharge is $23.40 \mathrm{~m}^{3} \cdot \mathrm{s}^{-1}$ on May and $27.51 \mathrm{~m}^{3} \cdot \mathrm{s}^{-1}$ on June. The discharge will be used as the historical base flow on May and June in Sutami reservoir.

The mean volume of historical direct flow on May is 98.82 billion $\mathrm{m}^{3}$ and on June is 12.10 billion $\mathrm{m}^{3}$, so the volume total of historical direct flow on $9^{\text {th }}$ May to $4^{\text {th }}$ June is 104.92 billion $\mathrm{m}^{3}$. However, total actual volume of direct flow on May is 159.67 billion $\mathrm{m}^{3}$ and on June is 23.09 billion $\mathrm{m}^{3}$, so the total volume of actual flow is 182.75 billion $\mathrm{m}^{3}$. The difference between the two values is as the success grade of the synthetic rainfall. The volume increasing of direct flow can be seen on the daily period of $9^{\text {th }}$ May to $4^{\text {th }}$ June. The increas- 
Table 11. Minimum inflow historical discharge in Sutami reservoir in 1991-2011

\begin{tabular}{|c|c|c|}
\hline Year & $\begin{array}{c}\text { Discharge of May } \\
\mathrm{m}^{3} \cdot \mathrm{s}^{-1}\end{array}$ & $\begin{array}{c}\text { Discharge of June } \\
\mathrm{m}^{3} \mathrm{~s}^{-1}\end{array}$ \\
\hline 1991 & 32.58 & 30.11 \\
\hline 1992 & 52.21 & 36.42 \\
\hline 1993 & 48.28 & 44.47 \\
\hline 1994 & 50.06 & 38.05 \\
\hline 1995 & 40.16 & 44.06 \\
\hline 1996 & 45.17 & 37.79 \\
\hline 1997 & 23.40 & 27.51 \\
\hline 1998 & 40.61 & 42.89 \\
\hline 1999 & 57.85 & 37.08 \\
\hline 2000 & 72.60 & 52.32 \\
\hline 2001 & 40.82 & 46.12 \\
\hline 2002 & 53.67 & 40.24 \\
\hline 2003 & 39.37 & 35.09 \\
\hline 2004 & 46.54 & 31.40 \\
\hline 2005 & 36.80 & 35.74 \\
\hline 2006 & 68.03 & 50.96 \\
\hline 2007 & 49.91 & 42.64 \\
\hline 2008 & 54.88 & 43.01 \\
\hline 2009 & 49.19 & 43.45 \\
\hline 2010 & 116.01 & 74.29 \\
\hline 2011 & 72.56 & 51.94 \\
\hline
\end{tabular}

Source: own study.

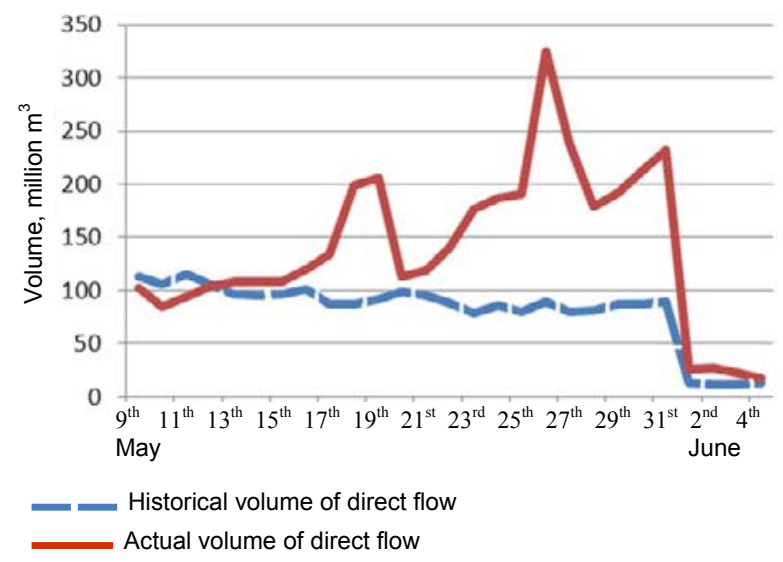

Fig. 3. Comparison between historical and actual volume of direct flow in Sutami reservoir $9^{\text {th }}$ May $-4^{\text {th }}$ June; source: own study

ing is seen from the ratio between historical and actual volume of direct flow. Figure 3 presents the comparison between historical and actual volume of direct flow.

The increasing of synthetic rainfall as the impact of synthetic rainfall in upstream Brantas watershed is significant. The increasing grade of the happening rainfall is over the historical one. The volume increasing of direct flow in Sutami reservoir due to the synthetic rainfall which is carried out on $9^{\text {th }}$ May to $4^{\text {th }}$ June 2013 can be analysed by seeing the difference between the volume mean of historical and actual direct flow. The analysis of direct flow volume increasing due to the synthetic rainfall on 2013 is as follow:

- historical direct flow volume $=104.92$ billion $\mathrm{m}^{3}$;

- actual direct flow volume $=182.75$ billion $\mathrm{m}^{3}$;
- the difference is $182.75-104.92$ billion $\mathrm{m}^{3}=77.84$ billion $\mathrm{m}^{3}$;

- the increasing is $77.84: 104.92 \cdot 100 \%=74.19 \%$.

The volume mean of historical direct flow is analysed by using historical data of inflow discharge in Sutami reservoir on the same date from 1991 to 2011. The volume mean of historical direct flow is 104.92 billion $\mathrm{m}^{3}$ and for the actual one is 182.75 billion $\mathrm{m}^{3}$. The actual volume is analysed by using the data on 2013 in Sutami reservoir. There is the increasing of $74.19 \%$. The result is at least partially by natural variation of direct flow volume in Sutami reservoir.

\section{CONCLUSIONS}

1. The rainfall mean of target area when the process of synthetic rainfall on the period of $9^{\text {th }}$ May to $4^{\text {th }}$ June 2013 is $183.42 \mathrm{~mm}$ and in control area is $83 \mathrm{~mm}$. Estimation of rainfall in target area based on the Linear Regression is $112.94 \mathrm{~mm}$ and the rainfall increasing is $62.40 \%$. Historical rainfall in target area is $68.32 \mathrm{~mm}$ and in control area is $77.93 \mathrm{~mm}$. Analysis of rainfall increasing based on the Double Ratio method produces the value of $D R$ is 2.52 , so the rainfall increasing is $152.05 \%$.

2. The increasing of rainfall in upstream Brantas watershed also causes the increasing on the flow volume in Sutami reservoir. The volume mean of historical flow is 104.92 billion $\mathrm{m}^{3}$ and the actual one is 182.75 billion $\mathrm{m}^{3}$. Therefore, the increasing of flow volume is $74.19 \%$.

\section{REFERENCES}

ARAGHINEJAD S. 2011. An approach for probabilistic hydrological drought forecasting. Water Resources Management. Vol. 25. Iss. 1 p. 191-200.

ASDAK C. 2001. Hidrologi dan pengelolaan daerah aliran sungai. [Hydrology and watershed management]. Yogyakarta. Gajah Mada University Press. ISBN 979-420737-3 pp. 646.

BĄK B., KUBIAK-WÓJCICKA K. 2017. Impact of meteorological drought on hydrological drought in Torun (Central Poland) in the period of 1971-2015. Journal of Water and Land Development. No. 32 p. 3-12. DOI 10.1515/ jwld-2017-0001.

Belyaeva M.V., Drofa A.S., Ivanov V.N., Kudsy M., HaRYanto U., GOENAWAN R.D., HaRSANTI D., RidWAN 2011. Studi model untuk peningkatan presipitasi awan konvektif dengan bubuk garam [Model study for improved convective cloud precipitation with salt powder]. Jurnal Sains dan Teknologi Modifikasi Cuaca. Vol. 2. No. 2 p. $37-41$.

BPPT 2013. Badan Pengkajian dan Penerapan Teknologi Indonesia (Department of Technological and Application, Indonesia) [online]. [Access 05.01.2017]. Available at: wxmod.bppt.go.id/

BPPT 2016. Monitoring [online]. Balai Besar Teknologi Indonesia (Great Institution of Technology, Indonesia). [Access 05.01.2017]. Available at: wxmod.bppt.go.id/

Kalyanapu A.J., SteVen J.B., McPherson T.N. 2009. Effect of land use-based surface roughness on hydrologic 
model output. Journal of Spatial Hydrology. Vol. 9. No. 2 p. 51-71.

HARTO S. 1993. Analisis hidrologi [Analysis of hydrology]. Jakarta. Gramedia Pustaka Utama. ISBN 979511235X. pp. 303.

Khezazna A., Amarchi H., Derdous O., Bousakhria F. 2017. Drought monitoring in the Seybouse Basin (Algeria) over the last decades. Journal of Water and Land Development. No. 33 p. 79-88. DOI 10.1515/jwld2017-0022.

Sekretariat Kabinet Republik Indonesia 2013. Laporan kegiatan pekerjaan teknologi modifikasi cuaca Indonesia [Activity report of climate change modification technol- ogy work Indonesia] [online]. [Access 05.01.2017]. Available at: http://www.setkab.go.id/nusantara-7149atasi-banjir-jakarta-bnpb-dan-bppt-gelar-modifikasicuaca.html

SoEmARTO C.D. 1987. Hidrologi teknik [Engineering hydrology]. Jakarta. Erlangga. ISBN 32002198 pp. 313.

SOSRODARSONO S. 1983. Hidrologi untuk pengairan [Hydrology for watering]. Jakarta. PT Pradnya Paramita. ISBN 979-408-108-6 pp. 226.

VAngelis H., Spiliotis M., TsakiRis G. 2011. Drought severity assessment based on bivariate probability analysis. Water Resources Management. Vol. 25. Iss. 1 p. $357-371$.

\section{Lily Montarcih LIMANTARA, Donny HARISUSENO, Rana Karinta HAPSARI}

\section{Ocena użycia sztucznego deszczu w relacji do natężenia przepływu w górnej części zlewni Brantas,} Prowincja Wschodniej Jawy, Indonezja

\section{STRESZCZENIE}

Indonezyjski Dział Technicznych Wdrożeń (UPT) Sztucznego Deszczu dokonał modyfikacji klimatu przez wygenerowanie sztucznego deszczu od 9 maja do 4 czerwca 2013 r. Dział ten współpracował z Departamentem Technologicznych Badań i Zastosowań (BPPT) Indonezji oraz z Perum Jasa Tirta I i z TNI AU Lanud Abdulrachman Saleh. Celem badań było podniesienie poziomu wody w zbiornikach na terenie górnej części zlewni Brantas. Jednym z tych zbiorników jest Sutami. Stopniowej oceny sztucznego opadu dokonano, używając metody dwustosunku i metody wielkości odpływu. Obiektem badań była górna część zlewni Brantas reprezentowana przez 12 posterunków pomiaru opadu i obszar kontrolny leżący ok. $30 \mathrm{~km}$ od granicy zlewni reprezentowany przez 5 posterunków opadowych. Wyniki wskazują wzrost opadu o $152,05 \%$ według metody dwustosunku i wzrost odpływu ze zbiornika Sutami o 74,19\% według metody wielkości odpływu.

Slowa kluczowe: dwustosunek, obszar badań, obszar kontrolny, sztuczny deszcz, wielkość odplywu 